\title{
Internet Usage and Risky Sexual Behavior among High School Students in a Suburban Area of Indonesia
}

\author{
Kusman Ibrahim ${ }^{1 * \mathbb{D}}$, Adriati Ajeng Juliana ${ }^{2}$, Dyah Setyorini ${ }^{3}$, Iqbal Pramukti ${ }^{3} \mathbb{D}$ \\ ${ }^{1}$ Department of Medical Surgical Nursing, Faculty of Nursing, Universitas Padjadjaran, Bandung, Indonesia; ${ }^{2}$ Department of \\ Fundamental Nursing, Faculty of Nursing, Universitas Padjadjaran, Bandung, Indonesia; ${ }^{3}$ Department of Community Health \\ Nursing, Faculty of Nursing, Universitas Padjadjaran, Bandung, Indonesia
}

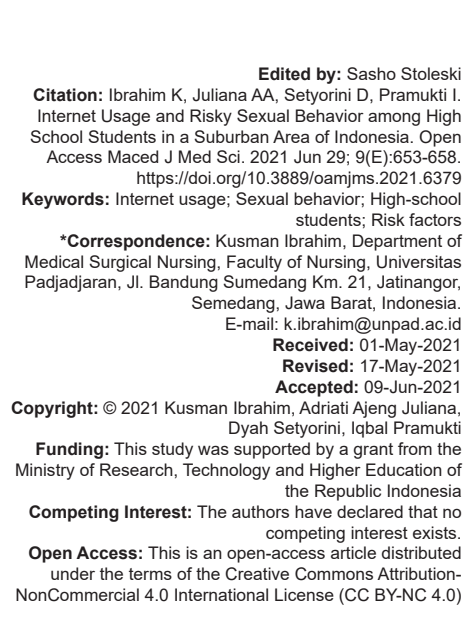

\section{Abstract}

BACKGROUND: Internet has been of great benefit to human life, however, it has some disadvantages which exis particularly among young people.

AIM: Therefore, this study aims to investigate the internet usage and risky sexual behavior among high schoo students in a suburban area in Indonesia.

METHODS: This was a cross-sectional study carried out using stratified random sampling in a high school located in a suburban area in West Java, Indonesia. Furthermore, self-administered Modified Internet Sex Screening Test (ISST) questionnaire was applied to measure the risky sexual behavior among the students.

RESULTS: The results showed that based on the overall risky sexual behavior from internet usage, $35(12.9 \%)$ $211(77.6 \%)$, and $26(9.6 \%)$ subjects were at low, medium, and high risk, respectively. Furthermore, the male gender and browsing for sexual content video were discovered to be the significant risk factors associated with risky sexua behavior with an adjusted odds ratio (AOR) of 5.79 (95\% Cl: 1.15-29.14) and 3.11 (95\% Cl: 1.03-9.39), respectively.

CONCLUSIONS: From the results obtained, it was concluded that the prevalence of risky sexual behavior based on internet usage is high among students. Furthermore, it was discovered that male students need more attention by being involved in healthy sexual education. In addition, the role of policy-maker in filtering the accessible content for students is required.

\section{Introduction}

Nowadays, the internet is an inseparable element in daily life for majority of modern individuals. Indonesia is the fourth most populous country in the world with a total of about 264 million and $64.8 \%$ of them (171 million) being able to access the internet as of 2018 [1]. Meanwhile, this number has continued to increase every year, with adolescents (aged 15-19 year) constituting majority of the internet users in the country. West Java is the most populous province in Indonesia, which is home to about 47 million Indonesians and accounts for the largest number of internet users $(16.7 \%)$ followed by Central $(14.3 \%)$ and East Java $(13.5 \%)$ [1]. This number has significantly increased due to the COVID-19 pandemic in the beginning of 2020 , when the government policy of "work from home" and "study from home" was implemented.

The advancement of information and communication technology, with internet as one of its products, has brought great benefits to many individuals in the world. It allows easy communication and connection, sharing of information, some businesses to be carried out, or just to have fun/entertain oneself. Therefore, the internet has made the life of many individuals easier and convenient. However, due to the availability of massive information, ability of individuals to store and retrieve whatever contents in line with their preference, and the availability of some unwanted elements, it is of disadvantage to some particular users, especially those not matured enough in terms of mental and intellect to process, select, and use the information wisely. This makes them vulnerable to the disadvantages of the effect and is most common among teenagers or young adult population [2]. A study survey, comprising 403 young individuals with internet access, discovered that $72 \%$ of them fell on pornographic sites, which influenced their sexual behavior such as engaging in oral sex, having multiple sexual partners and homosexuality. Therefore, seeing pornographic movies either online or offline is an associated factor to risky sexual behaviors among high school students [3].

Adolescence or young adult is one of the most rapid phases of human development. It is a transition from childhood to adulthood, which is characterized by physical and neurohormonal changes and in some instances, biological maturity comes earlier than psychosocial 
maturity [4]. Furthermore, some behaviors may develop during adolescence stage such as high levels of risk taking, exploration, novelty and sensation seeking, social interaction, and play behaviors [5]. In addition, this is the age to explore and understand sexuality. Sexual curiosity among adolescents has led to exposure to pornography, indulgence in sexual activities, and also an increase in the vulnerability to sexual abuse [6]. Meanwhile, several factors influence their sexual behavior such as physical maturation, psychological factors, social factors, cultural norms, and past experiences. At present, the internet has advanced both socially and technologically, which influences the attitudes and perception of adolescents on sexuality. Furthermore, the extensive information related to sexuality available on internet has significant impact on sexual behavior. In addition, the place of residence was found as a predictor of sexual behavior among adolescence. A recent meta-analytic found that male adolescence in urban areas was 2.6 times likely to have higher risk sexual behavior than those in suburban areas [7].

Recently, internet usage among adolescents is inevitable due to many purposes and reasons. A study carried out by UNICEF and Ministry of Communication and Information, Indonesia, reported that $98 \%$ of the subjects ( $n=400)$ were knowledge about the internet and $79.5 \%$ were users [8]. Furthermore, it was reported that the subjects had at least three motives for accessing the internet, which include searching information, connect with friends, and have fun/entertainment. This easy access and ability to hide one's identity makes it easy to be exposed to sexual related contents that influence one's sexual behavior. A study carried out in Australia showed that sexually active young individuals are at risk of sexual transmitted infections and may engage in substance use risk behaviors [9]. Furthermore, risky sexual behavior appears to have implications on sexual reproductive health among adolescence population. Meanwhile, in Indonesia, information about sexual behavior is very limited due to social norms and cultural beliefs, which view sexual matters as taboo and private. Therefore, this study aims to investigate the internet usage and risky sexual behavior among high school students in a sub-urban area in Indonesia.

\section{Methods}

\section{Study design, participants, and measures}

This is a cross-sectional study, carried out in a high school located in a suburban area in West Java, Indonesia. A total of 272 students were recruited using stratified random sampling from the $10^{\text {th }}$ and $11^{\text {th }}$ grade.

The questionnaire used consisted of seven items, which measured demographic characteristic and internet usage and 25 items measuring sexual behavior. Furthermore, the validity and reliability of the instrument was assessed, and it yielded an internal consistency with the Cronbach alpha $\geq 0.88$. For the 25 items measuring sexual behavior, self-administered modified Internet Sex Screening Test (ISST) questionnaire was applied [10]. It had a score range from 1 to 25 with three categories including low risk (score of 1-8), at risk (score of 9-18), and high risk (score $>18$ ).

\section{Data analysis}

Descriptive statistical techniques were carried out to describe demographic, internet usage, and sexual behavior. Furthermore, Chi-square test was employed to examine the risk of sexual behavior on the internet according to subject's characteristic, which include gender, age, have ever accessed sexual contents, experience of having sexual intercourse, time spent accessing the internet daily, platform of social media used, and browsing sexual content video. A one-way ANOVA was used to compare the difference in normally distributed variables, while a logistic regression was used to determine the risk factor for risky sexual behavior on the internet. Meanwhile, all statistical analyses were performed using IBM-SPSS software version 23 for Mac.

\section{Ethical consideration}

The protocol implemented in this study was reviewed and approved by the Health Research Ethics Committee of Universitas Padjadjaran (Letter No. 876/ UN.6.KEP/EC/2019). Furthermore, permission for data collection was granted by the head of school where it was carried out (Letter No. 074/198/SMAN/CADISDIK. WIL VIII/2019). A written informed consent was also provided by the subjects involved in this study.

\section{Results}

\section{Demographic characteristics and internet} usage

The subjects were primarily females $(n=162$, $59.6 \%$ ). The mean age of the subjects was 16.2 years (SD 0.72) (Table 1). Nearly all subjects had gadgets with internet access $(n=266,97.8 \%)$. Meanwhile, a total of $252(92.6 \%)$ subjects were frequent, 16 (5.9\%) were not frequent and $4(1.5 \%)$ never accessed the internet. Furthermore, most subjects spent the time between $3-10 \mathrm{~h}$, weekly accessing the internet $(n=173,63.6 \%)$, while $64(23.5 \%)$ spent $<3 \mathrm{~h}$ and $4(1.5 \%)$ spent more than $10 \mathrm{~h}$. The most frequently used social media platforms were WhatsApp ( $\mathrm{n}=262,96.3 \%)$, Instagram 
( $n=240,88.2 \%$ ), and YouTube ( $n=199,73.2 \%)$. In addition, those that accessed the internet from home ( $n=86,86.9 \%$ ) were higher compared to those outside $(n=13,13.1 \%)$. Nearly all subjects accessed sexual content $(n=99,36.4 \%)$ and only $3(1.1 \%)$ were discovered to be involved in sexual-related groups on social media. Among the sexual orientation group, the heterosexual group showed the highest percentage ( $n=267,98.2 \%)$.

Table 1: Demographic characteristics and internet access of the participants $(n=272)$

\begin{tabular}{|c|c|}
\hline Characteristic & $\mathrm{n}(\%)$ \\
\hline \multicolumn{2}{|l|}{ Age (years) } \\
\hline Mean (SD) & $16.2(0.72)$ \\
\hline \multicolumn{2}{|l|}{ Sex } \\
\hline Female & $162(59.6)$ \\
\hline Male & $110(40.4)$ \\
\hline \multicolumn{2}{|l|}{ Owning gadget } \\
\hline Yes & $266(97.8)$ \\
\hline No & $6(2.2)$ \\
\hline \multicolumn{2}{|l|}{ Access to internet } \\
\hline Have access & $266(97.8)$ \\
\hline Do not have access & $6(2.2)$ \\
\hline \multicolumn{2}{|l|}{ Accessing internet } \\
\hline Always & $252(92.6)$ \\
\hline Sometimes & $16(5.9)$ \\
\hline Never/very rare & $4(1.5)$ \\
\hline \multicolumn{2}{|l|}{ Daily internet usage $^{a}$} \\
\hline$<3 \mathrm{~h}$ & $64(23.5)$ \\
\hline $3-10 \mathrm{~h}$ & $173(63.6)$ \\
\hline$>10 \mathrm{~h}$ & $35(12.9)$ \\
\hline \multicolumn{2}{|l|}{ Platform of social media used } \\
\hline LINE & $137(50.4)$ \\
\hline Instagram & $240(88.2)$ \\
\hline WhatsApp & $262(96.3)$ \\
\hline Twitter & $48(17.6)$ \\
\hline Facebook & $129(47.4)$ \\
\hline Skype & $6(2.2)$ \\
\hline YouTube & $199(73.2)$ \\
\hline Snapchat & $64(23.5)$ \\
\hline Others & $11(4.0)$ \\
\hline \multicolumn{2}{|l|}{ Place of accessing internet } \\
\hline Home & $86(86.9)$ \\
\hline Outside & $13(13.1)$ \\
\hline \multicolumn{2}{|l|}{ Accessing sexual content } \\
\hline Yes & $99(36.4)$ \\
\hline No & $173(63.6)$ \\
\hline \multicolumn{2}{|c|}{ Involving in sexual-related groups in social media } \\
\hline Involved & $3(1.1)$ \\
\hline Not involved & $269(98.9)$ \\
\hline \multicolumn{2}{|l|}{ Sexual orientation } \\
\hline Heterosexual & $267(98.2)$ \\
\hline Homosexual (gay/lesbian) & $2(0.7)$ \\
\hline Bisexual & $3(1.1)$ \\
\hline \multicolumn{2}{|l|}{ Had sexual intercourse } \\
\hline Ever had & $2(0.7)$ \\
\hline Not ever had & $270(99.3)$ \\
\hline
\end{tabular}

\section{The risk of sexual behavior on the internet} according to subject's characteristic

For the overall risk of sexual behavior on the internet, 35 (12.9\%) were identified as low risk, $211(77.6 \%)$ were at risk, and $26(9.6 \%)$ were at high risk (Figure 1 and Table 2). Among the high-risk group, the males showed a higher percentage $(n=24,92.3 \%)$ compared to the females, while they were lower in the low risk $(n=8,22.9 \%)$ and at-risk group $(n=78,37.0 \%)$. Furthermore, the proportion of male, having their own gadget, engaging in sexual intercourse, and high-risk sexual behavior were higher compared to females with neither gadget nor engaged in sexual intercourse (Table 2).

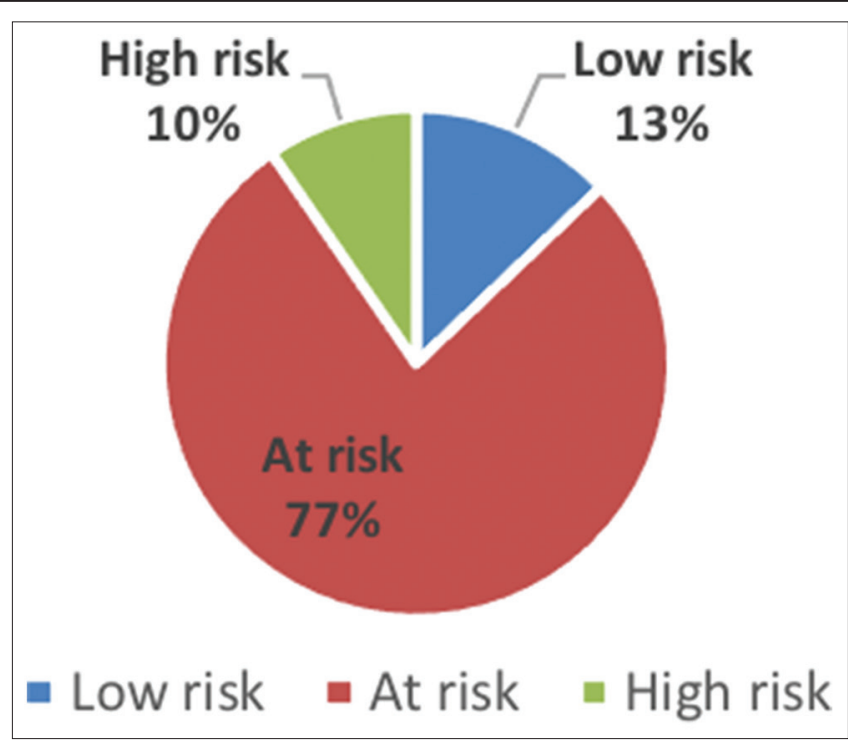

Figure 1: Proportion of risk level of sexual behavior on the internet among high school students

\section{Knowledge on consequences of engaging risky sexual behavior}

From the 272 subjects, 196 (72.1\%) had good knowledge on the consequence of engaging in risky sexual behavior, while 161 (59.2\%) knew the consequence of HIV and 35 (12.9\%) thought that there was no effect of engaging in risky sexual behaviors (Figure 2).

Table 2: Risk of sexual behavior on the internet according to subject characteristic $(n=272)$

\begin{tabular}{|c|c|c|c|c|}
\hline \multirow[t]{3}{*}{ Variable } & \multicolumn{3}{|l|}{ Risk level } & \multirow[t]{3}{*}{$p$ value } \\
\hline & \multirow{2}{*}{ Low risk } & \multirow{2}{*}{$\begin{array}{l}\text { At risk } \\
\mathrm{n}(\%)\end{array}$} & \multirow{2}{*}{$\begin{array}{l}\text { High risk } \\
\mathrm{n}(\%)\end{array}$} & \\
\hline & & & & \\
\hline Overall & $35(12.9)$ & $211(77.6)$ & $26(9.6)$ & \\
\hline Sex, male (\%) & $8(22.9)$ & $78(37.0)$ & $24(92.3)$ & $<0.001^{* *}$ \\
\hline Age & $16.3(0.8)$ & $16.1(0.7)$ & $16.4(0.8)$ & 0.077 \\
\hline Accessing sexual content & $0(0.0)$ & $73(34.6)$ & $26(100.0)$ & $<0.001 * *$ \\
\hline Had sexual intercourse experience & $0(0.0)$ & $0(0.0)$ & $2(7.7)$ & $<0.001 * *$ \\
\hline Daily internet usage $^{a}$ & & & & 0.911 \\
\hline$<3 \mathrm{~h}$ & $9(25.7)$ & $48(22.7)$ & $7(26.9)$ & \\
\hline $3-10 \mathrm{~h}$ & $22(62.9)$ & $134(63.5)$ & $17(65.4)$ & \\
\hline$>10 \mathrm{~h}$ & $4(11.4)$ & 29 (13.7) & $2(7.7)$ & \\
\hline \multicolumn{5}{|l|}{ Platform of social media used } \\
\hline LINE & $16(45.7)$ & $111(52.6)$ & $10(38.5)$ & 0.333 \\
\hline Instagram & $29(82.9)$ & $186(88.2)$ & $25(96.2)$ & 0.280 \\
\hline WhatsApp & $34(97.1)$ & $202(95.7)$ & $26(100.0)$ & 0.531 \\
\hline Twitter & $4(11.4)$ & $36(7.1)$ & $8(30.8)$ & 0.131 \\
\hline Facebook & $14(40.0)$ & $100(47.4)$ & $15(57.7)$ & 0.392 \\
\hline Skype & $0(0.0)$ & $5(2.4)$ & $1(3.8)$ & 0.566 \\
\hline YouTube & $2160.0)$ & $158(74.9)$ & $20(76.9)$ & 0.399 \\
\hline Snapchat & $7(20.0)$ & $55(26.1)$ & $2(7.7)$ & 0.099 \\
\hline Browsing for sexual content video & $0(0.0)$ & $31(42.5)$ & $18(69.2)$ & $0.019 *$ \\
\hline
\end{tabular}

\section{the internet}

\section{Risk factor for risky sexual behavior on}

A logistic regression was applied to analyze risk factors for risky sexual behavior (ISST score > 9) (Table 3). The final model showed that the male gender and browsing for sexual content video were the most significant risk factors associated with risky sexual behavior with an adjusted odds ratio (AOR) of 5.79 (95\% 
$\mathrm{Cl}$ : 1.15-29.14) and 3.11 (95\% Cl: 1.03-9.39), respectively.

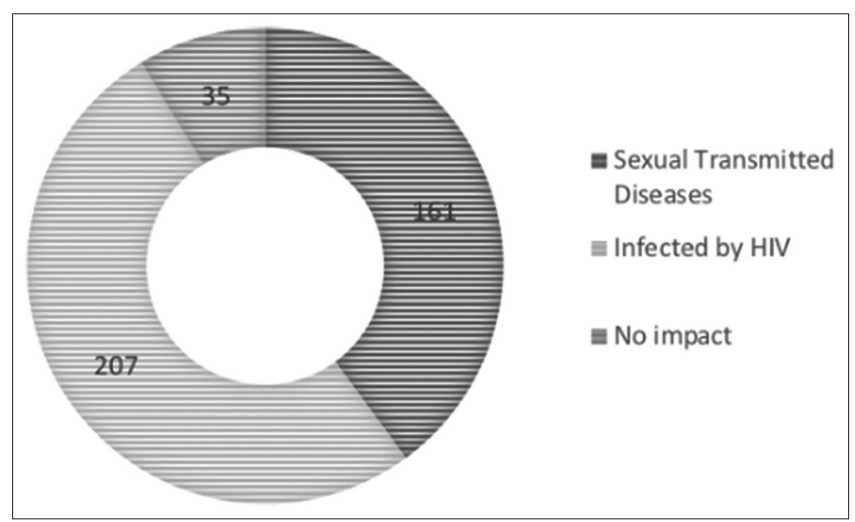

Figure 2: Knowledge-related impact of engaging risky sexual behavior

\section{Discussion}

From this study, it was discovered that almost all subjects have internet access. This was congruent with the data from APJII (2018), which showed that majority $(91 \%)$ of adolescents were internet users in Indonesia [1]. Furthermore, it was discovered that over three-fourth students spent more than $3 \mathrm{~h}$ daily accessing the internet. The previous studies also showed that $64.9 \%(n=97)$ of high school students spend more than $6 \mathrm{~h}$ a day on the internet [11]. The internet has penetrated to approximately $64.8 \%$ of Indonesian population, with over $70 \%$ of the urban population having access. In the demographic figure, adolescent (10-19 years) constituted almost $20 \%$ of the population. This is because the internet has become a daily lifestyle for most young adult throughout the world including in Indonesia.

Table 3: Multivariate logistic regression assessing risk factor for risky sexual behavior

\begin{tabular}{lllllll}
\hline Variable & $\mathrm{OR}$ & $\mathrm{Cl}$ & $\mathrm{p}$-value & $\mathrm{AOR}$ & $\mathrm{Cl}$ & $\mathrm{p}$-value \\
\hline Sex, male & 22.32 & $5.15-96.72$ & $<0.001$ & 5.79 & $1.15-29.14$ & $0.033^{*}$ \\
Twitter user & 2.29 & $0.93-5.62$ & 0.071 & 3.94 & $0.97-16.03$ & 0.056 \\
Snapchat user & 0.25 & $0.06-1.08$ & 0.063 & 0.14 & $0.02-1.16$ & 0.069 \\
$\begin{array}{l}\text { Browsing for sexual } \\
\text { content video }\end{array}$ & 3.05 & $1.18-7.91$ & 0.022 & 3.11 & $1.03-9.39$ & $0.045^{*}$ \\
\hline & & & & & \\
\hline OR: Odds ratio; Cl: Confidence interval; AOR: Adjusted odds ratio; ${ }^{*}$ refers to $p<0.05$. &
\end{tabular}

In addition, from this study, it was discovered that over three-fourth of the subjects were at risk or high risk of sexual behavior on the internet. Meanwhile, onethird has accessed sexual-related contents from the internet in the form of video, movie, picture, text, etc., and a few of them were involved in sexual-related social media groups, even engaging in sexual relationship. Although, the number was small, the implication could be serious as they have the ability to influence their friends by exposing them to internet pornography. As a previous study pointed out, peer pressure is one of the reasons why young adults access the internet and perhaps stumble into Sexual Explicit Internet Materials (SEIM) which might have impact on their sexual behavior [12]. Another study also found that young adults tends may hence use SEIM more frequently than older adults [13]. A study also showed that nearly half of the subjects browsed for sexual content through the internet [14]. Another study documented the association between pornography exposure and sexual behaviors [15]. It showed that young men that frequent the internet and exposed to SEIM are more likely to report a change in sexual behavior such as engaging in oral sex, body tattoo, having multiple sexual partners, and homosexuality [2]. Furthermore, in this study, five subjects were discovered to have sexual orientation to the same sex or both. Although, it is still a small number, this phenomenon is raising concern in Indonesia since the number of man having sex with men (MSM) has be proven to be the highest number of risk population of getting HIV and has replaced the People Who Inject Drugs (PWID) and heterosexual that have been the dominant risk group of HIV infection over years [16]. Indonesia is considered as the biggest Muslim population country in the world, which views MSM or in a common term called LGBT (lesbian, gay, bisexual, and transgender) as illegal practices and, therefore, is strictly prohibited by law including religious beliefs and social norms [17]. Individuals engaging in this kind of practice usually hide themselves from the public spaces, yet exist in social media.

Majority of subjects in this study have a good knowledge about the consequences of engaging in risky sexual behavior on their health, especially contracting HIV and sexual transmitted diseases. However, there were still few of them ignorant about the significant impact of risky sexual behavior on their sexual reproductive health. High school students were reported to show poor level of sexual health knowledge and still have some misconceptions about sexual issues [18]. Furthermore, the results obtained proved that sexual health knowledge is significantly associated with current educational status, age, and sexual orientation. As previous study found that the students' experience of school-based sexuality education may be positively associated with their knowledge level about sexuality [19]. In addition, homosexual and bisexual students had a mean score of knowledge lower than heterosexual. This implies that knowledge about reproductive health still needs to be disseminated among high school students since they are internet friendly generation with high possibility of being exposed to SEIM.

The important discovery made in this study was that there were significant differences among the levels of sexual risk behavior with regard to sex, accessing sexual content, having sexual intercourse, and browsing for sexual content video. Male students that are yet to access sexual contents and have sexual intercourse were more likely to have higher risk sexual behavior compared to females. Although, high-risk 
behavior does not always manifest in actual behavior from having sexual intercourse, yet the previous studies have reported that exposure to internet pornography influences the change in sexual behavior, particularly among young males [2], [20]. Furthermore, they are more likely to be at high risk of accessing sexual related content from the internet. This was also congruent with the previous studies reported that male students are 2.5 times more at risk compared to female students (AOR: 2.507, 95\% Cl: 1.370-4.560) [21].

Another important discovery is the significant factors related to risky sexual behavior among high school students including male sex and browsing for sexual content video. The higher risky sexual behavior among male students compared to female students also found in earlier study in Spain [22]. In Asia, similar finding also found among poor Myanmar youth [23]. The potential reason may be due to their online behavior. When students receiving sexual content visual stimuli, male students appeared more influenced than female [24]. The previous studies showed that browsing for sexual content video is a significant factor related to high-risk sexual behavior [25]. This correlation may be due to the occurrence of imitating process among adolescent after seeing sexual content video through internet. Earlier studies found that sexual behavior can be acquired through imitating and copying of sexual behavior acted by the sexual model on the internet [26], [27]. Another study showed that peer group, parents' control, self-efficacy, and sex are other significant factors for risky sexual behavior [28]. Even, it was found to have association between texting in communication media and sexual behaviors among adolescent students [28].

The limitations of our study include the following: (1) lack of information on place of accessing internet due to limited information retrieved from the subjects; (2) the fact that Indonesian high-school students were not familiar with certain type of social media and certain type of streaming platform; (3) this study only focus in one area of suburban which limits its generabilility to the whole student population of the country.

\section{Implication for school health}

The results of this study highlighted the high prevalence of students with risky sexual behavior on the internet, particularly male students. Although, it was discovered that a few subjects were not knowledgeable about the consequence of engaging in risky sexual behavior and they would be a potential group to negatively influence other students to get involved in risky sexual behaviors. Therefore, community nurses, teachers, parents, and policy-makers need to take proactive approaches to prevent the unhealthy sexual behavior among students due to access to sexual explicit internet materials. Furthermore, sex education combined with skills of using internet media wisely and smartly is necessary to equip students in facing negative effects of using internets and social media.

\section{Human subjects approval statement}

The protocol implemented in this study was reviewed and approved by the Health Research Ethics Committee of Universitas Padjadjaran (Letter No. 876/ UN.6.KEP/EC/2019). Furthermore, permission for data collection was granted by the head of school where it was carried out (Letter No. 074/198/SMAN/CADISDIK. WIL VIII/2019). A written informed consent was also provided by the subjects involved in this study.

\section{Conclusions}

The results of this study highlighted the high prevalence of students with risky sexual behavior on the internet, particularly male students. Although, it was discovered that a few subjects were not knowledgeable about the consequence of engaging in risky sexual behavior and they would be a potential group to negatively influence other students to get involved in risky sexual behaviors. Therefore, community nurses, teachers, parents and policy makers need to take proactive approaches to prevent the unhealthy sexual behavior among students due to access to sexual explicit internet materials. Furthermore, sex education combined with skills of using internet media wisely and smartly is necessary to equip students in facing negative effects of using internets and social media.

\section{Acknowledgments}

The authors express gratitude to the Ministry of Research, Technology and Higher Education of the Republic Indonesia for providing study grant and the University of Padjadjaran for in kind support. Furthermore, to the head school of the study setting for their permission and cooperation while carrying out this study and the subjects for their time and information provided.

\section{References}

1. APJII. Hasil Survei Penetrasi dan Perilaku Pengguna Internet Indonesia; 2018. Available from: https://apjii.or.id/content/ read/39/410/Hasil-Survei-Penetrasi-dan-Perilaku-PenggunaInternet-Indonesia-2018. 
2. Arulogun OS, Ogbu IA, Dipeolu IO. Influence of internet exposure on sexual behaviour of young persons in an urban district of Southwest Nigeria. Pan Afr Med J. 2016;25:261. https://doi.org/10.11604/pamj.2016.25.261.2630

PMid:28293377

3. Girmay A, Mariye T. Risky sexual behavior practice and associated factors among secondary and preparatory school students of Aksum town, Northern Ethiopia, 2018. BMC Res Notes. 2019;12(1):698. https://doi.org/10.1186/ s13104-019-4714-1

PMid:31655614

4. World Health Organization. Adolescent Health and Development. Geneva: World Health Organization; 2020 Available from: https://www.who.int/news-room/q-a-detail/ adolescent-health-and-development.

5. Crews F, He J, Hodge C. Adolescent cortical development: A critical period of vulnerability for addiction. Pharmacol Biochem Behav. 2007;86(2):189-99. https://doi.org/10.1016/j. pbb.2006.12.001

PMid:17222895

6. Kar SK, Choudhury A, Singh AP. Understanding normal development of adolescentsexuality:Abumpy ride. J Hum Reprod Sci. 2015;8(2):70-4. https://doi.org/10.4103/0974-1208.158594 PMid:26157296

7. Berhan Y, Berhan A. A meta-analysis of risky sexual behaviour among male youth in developing countries. AIDS Res Treat. 2015;2015:580961. https://doi.org/10.1155/2015/580961 PMid:25709840

8. Kominfo. Riset Kominfo dan UNICEF Mengenai Perilaku Anak dan Remaja Dalam Menggunakan Internet. Jakarta: Kominfo; 2014. Available from: https://kominfo.go.id/ content/detail/3834/siaran-pers-no-17pihkominfo22014tentang-riset-kominfo-dan-unicef-mengenai-perilakuanak-dan-remaja-dalam-menggunakan-internet/0/ siaran_pers.

9. Kang M, Rochford A, Skinner SR, Mindel A, Webb M, Peat J, et al. Sexual behaviour, sexually transmitted infections and attitudes to chlamydia testing among a unique national sample of young Australians: Baseline data from a randomised controlled trial. BMC Public Health. 2014;14:12. https://doi. org/10.1186/1471-2458-14-12

PMid:24400743

10. Delmonico D, Miller J. The internet sex screening test: A comparison of sexual compulsives versus non-sexual compulsives. Sex Relat Ther. 2003;18(3):261-76. https://doi. org/10.1080/1468199031000153900

11. Ibrahim M, Suryani S, Sriati A. Relationship external factors with internet addiction in adolescent age 15-18 years. J Keperawatan Padjadjaran 2019;7:1105. https://doi.org/10.24198/jkp. v7i3.1105

12. Anderson M, Jiang J. Teens, Social Media and Technology; 2018. Available from: https://www.pewresearch.org/ internet/2018/05/31/teens-social-media-technology-2018/.

13. Peter J, Valkenburg PM. The use of sexually explicit internet material and its antecedents: A longitudinal comparison of adolescents and adults. Arch Sex Behav. 2011;40(5):1015-25. https://doi.org/10.1007/s10508-010-9644-x PMid:20623250

14. Doring N, Daneback K, Shaughnessy K, Grov C, Byers ES. Online sexual activity experiences among college students: A fourcountry comparison. Arch Sex Behav. 2017;46(6):1641-52. https://doi.org/10.1007/s10508-015-0656-4

PMid:26659580
15. Hald GM, Mulya TW. Pornography consumption and non-marital sexual behaviour in a sample of young Indonesian university students. Cult Health Sex. 2013;15(8):981-96. https://doi.org/10 $.1080 / 13691058.2013 .802013$ PMid:23782270

16. Indonesia Health Profile 2018. Jakarta; 2019. Available from: https://pusdatin.kemkes.go.id/resources/download/pusdatin/ profil-kesehatan-indonesia/PROFIL_KESEHATAN_2018_1.pdf.

17. Harahap RD. LGBT DI INDONESIA: Perspektif hukum Islam, HAM, psikologi dan pendekatan Mașlahah. Al Ahkam. 2016;26(2):26. https://doi.org/10.21580/ahkam.2016.26.2.991

18. Visalli G, Cosenza B, Mazzu F, Bertuccio MP, Spataro P, Pellicano GF, et al. Knowledge of sexually transmitted infections and risky behaviours: A survey among high school and university students. J Prev Med Hyg. 2019;60(2):E84-92. PMid:31312737

19. Li C, Cheng Z, Wu T, Liang X, Gaoshan J, Li L, et al. The relationships of school-based sexuality education, sexual knowledge and sexual behaviors-a study of 18,000 Chinese college students. Reprod Health. 2017;14(1):103. https://doi. org/10.1186/s12978-017-0368-4 PMid:28841895

20. Lin $\mathrm{WH}$, Liu $\mathrm{CH}$, Yi CC. Exposure to sexually explicit media in early adolescence is related to risky sexual behavior in emerging adulthood. PLoS One. 2020;15(4):e0230242. https:// doi.org/10.1371/journal.pone.0230242 PMid:32275669

21. Seyfu H, Yohannes T. Risky sexual behavior and associated factors among reproductive age group high school students: Institution based cross sectional study. Epidemiol Open Access. 2018;8(2):344. https://doi.org/10.4172/2161-1165.1000344

22. Puente $\mathrm{D}$, Zabaleta $\mathrm{E}$, Rodríguez-Blanco $\mathrm{T}$, Cabanas $\mathrm{M}$, Monteagudo M, Pueyo MJ, et al. Gender differences in sexual risk behaviour among adolescents in Catalonia, Spain. Gac Sanit. 2011;25(1):13-9. https://doi.org/10.1016/j.gaceta.2010.07.012 PMid:21315492

23. Thin Zaw PP, Liabsuetrakul T, McNeil E, Htay TT. Gender differences in exposure to $\mathrm{SRH}$ information and risky sexual debut among poor Myanmar youths. BMC Public Health. 2013;13(1):1122. https://doi.org/10.1186/1471-2458-13-1122

24. Rupp HA, Wallen K. Sex differences in response to visual sexual stimuli: A review. Arch Sex Behav. 2008;37(2):206-18. https://doi.org/10.1007/s10508-007-9217-9 PMid:17668311

25. Landry M, Turner M, Vyas A, Wood S. Social media and sexual behavior among adolescents: Is there a link? JMIR Public Health Surveill. 2017;3(2):e28. https://doi.org/10.2196/ publichealth.7149 PMid:28526670

26. Adebayo DO, Udegbe IB, Sunmola AM. Gender, internet use, and sexual behavior orientation among young Nigerians. Cyberpsychol Behav. 2006;9(6):742-52. https://doi.org/10.1089/ cpb.2006.9.742 PMid: 17201600

27. Odeyemi K, Onajole A, Ogunowo B. Sexual behavior and the influencing factors among out of school female adolescents in Mushin market, Lagos, Nigeria. Int J Adolesc Med Health. 2009;21(1):101-9. https://doi.org/10.1515/ijamh.2009.21.1.101 PMid: 19526700

28. Etrawati F, Martha E, Damayanti R. Psychosocial Determinants of Risky Sexual Behavior among Senior High School Students in Merauke District. Kesmas. 2017;11(3):1163. https://doi. org/10.21109/kesmas.v11i3.1163 